\title{
Performance of the INCONEL 625 alloy weld overlay obtained by FCAW process
}

\author{
Camila Pereira Alvarães ${ }^{1}$, Francisco Carlos Albuquerque Madalena ${ }^{2}$, \\ Luís Felipe Guimarães de Souza ${ }^{1}$, Jorge Carlos Ferreira Jorge ${ }^{1}$, \\ Leonardo Sales Araújo ${ }^{3}$, Matheus Campolina Mendes ${ }^{1}$
}

\footnotetext{
${ }^{1}$ Centro Federal de Educação Tecnológica Celso Suckow da Fonseca, CEFET/RJ, Diretoria de Pesquisa e Pós-graduação, DIPPG, Rio de Janeiro, Rio de Janeiro, Brasil.

${ }^{2}$ PETROBRAS - E\&P-ENG/IPP/EISA, Rio de Janeiro, Rio de Janeiro, Rio de Janeiro, Brasil.

${ }^{3}$ Universidade Federal do Rio de Janeiro, UFRJ, Instituto Alberto Luiz Coimbra de Pós-graduação e Pesquisa de Engenharia, COPPE, Rio de Janeiro, Rio de Janeiro, Brasil.

e-mail: camila.alvaraes@gmail.com, lfgs59@gmail.com, jorgecfjorge@gmail.com, campolinamendes@gmail.com, fcmadalena@gmail.com, leonardo.sales@gmail.com
}

\begin{abstract}
Nickel-based weld overlays (cladding) are commonly used in oil \& gas industry to extend the life of equipment under corrosive environment, as it improves the corrosion resistance without a significant increase in the manufacturing cost, when compared to a full nickel-based alloy equipment. Although there are extensive literature involving overlays applied by SMAW, GMAW or GTAW processes, works about the use of FCAW process are limited. Consequently, an investigation of the performance of the overlays deposited by this process, which provides a higher productivity in comparison to the processes usually used, can be an interesting option for this application.

The present work evaluates the mechanical and microstructural properties of the nickel-based superalloy 625 weld overlay deposited on a ASTM A516 Grade 70 carbon steel plate by the flux cored arc welding process (FCAW), both in as welded and heat treated conditions. Bending and microhardness tests were performed in order to verify possible effects of welding thermal cycles on the mechanical properties. The microstructure was evaluated through both optical (OM) and scanning electron microscopy (SEM), with the use of electron backscatter diffraction (EBSD) technique. Corrosion tests were conducted on samples removed from the top layer of the weld overlay according to ASTM G 48 Method A. All results obtained with this welding process, in both as welded and heat treated samples, were considered satisfactory.
\end{abstract}

Keywords: Clad; Inconel 625; FCAW; post weld heat treatment.

\section{INTRODUCTION}

According to TRINDADE et al. [1], although C-Mn steel pipes are extensively applied in the oil \& gas industry, the challenge to overcome the corrosion severity caused by sour $\left(\mathrm{H}_{2} \mathrm{~S}, \mathrm{CO}_{2}\right)$ species present in the petroleum and its derivates is still a big issue. An interesting technological solution would be to replace the C-Mn steel by Ni-based superalloys. Nickel-based superalloy Inconel-625 is widely used in aeronautical, aerospace, chemical, petrochemical and marine industries due to its good combination of mechanical properties, weldability and resistance to high-temperature oxidation/corrosion on prolonged exposure to aggressively hostile environments [2-5]. The performance of Ni-based alloys is associated with the face-centered cubic (FCC) matrix that can be strengthened by solid-solution hardening, carbide precipitation and/or precipitation hardening of intermetallics. Iron, chromium, molybdenum, niobium, tungsten, titanium and aluminum are solidsolution hardening elements in nickel alloys [6].

However, the high cost of superalloys limits their application from an economic point of view $[1,4,5,7,8]$. Consequently, in order to provide a cost-effective solution for this engineering challenge, cladding or overlays with nickel-based alloys enters more and more into the focus of engineers [1,4]. In comparison with other methods, weld overlays are characterized by strong metallurgical bonding with the base material, due to the interpenetration of the deposited and supporting materials; it is also relatively easy to produce an overlay free from pores or other defects [9]. In this respect, there are several initiatives in order to develop overlays and/or cladding procedures using nickel-based superalloys as an alternative for manufacturing equipment whose external or internal surfaces require specific properties [5,7-19]. 
Usually, weld overlays are deposited by gas metal arc welding (GMAW) and gas tungsten arc welding (GTAW) processes [3,4,7,10,11,14,17-22]. GTAW is very often used for cladding of critical parts especially for offshore subsea equipment due to its very high quality welds, while GMAW is the most applied welding process in Europe, United States of America and Japan due to its higher deposition rate [4]. In order to evaluate the possibility of an additional increase on the productivity by the use of another welding process as versatile as GMAW, an investigation of the performance of the overlays deposited by flux cored arc welding process (FCAW) can be an interesting option for this application.

Considering that literature about the use of FCAW process is limited, this work evaluates the mechanical, microstructural and corrosion properties of the Inconel 625 alloy weld overlays in both as welded and post weld heat treated conditions deposited by flux cored arc welding process (FCAW) on ASTM A516 Grade 70 carbon steel base metal, due to the higher deposition rate promoted by this welding process when compared to others. The effect of post welding heat treatment is also studied, since sometimes it is recommended to relief residual stress, reduce hydrogen content or homogenize the microstructure [10, 19, 23, 24].

\section{MATERIALS AND METHODS}

ASTM A516 Gr. 70 carbon steel plates with dimensions of $12.5 \times 200 \times 230 \mathrm{~mm}$ (thickness $\mathrm{x}$ width $\mathrm{x}$ length) were used as substrate material. The weld overlay was produced with a $1.2 \mathrm{~mm}$-diameter wire with the chemical composition based on AWS ENiCrMo3T1-4 specification [25], resulting in a nickel-based superalloy 625 weld overlay. Table 1 shows the chemical composition of both materials.

Table 1: Chemical composition of the filler and base metal (wt \%).

\begin{tabular}{l|c|c|c|c|c|c|c|c}
\hline \multicolumn{1}{c|}{ MATERIAL / ELEMENT } & $\mathbf{C}$ & $\mathbf{S i}$ & $\mathbf{M n}$ & $\mathbf{N i}$ & $\mathbf{C r}$ & $\mathbf{M o}$ & $\mathbf{N b}$ & $\mathbf{F e}$ \\
\hline ASTM A 516 Gr. 70 - Base Material & 0.15 & 0.2 & 0.95 & 0.01 & 0.02 & 0.01 & - & Bal. \\
\hline Consumable & 0.05 & 0.4 & 0.4 & Bal. & 21.0 & 8.5 & 3.3 & $<1.0$ \\
\hline
\end{tabular}

Welding was performed at flat position with forty passes in three layers by the FCAW process, as schematically illustrated in Figure 1. A 5-mm-thick cladding was obtained, being this dimension above the required 3-mm-thick weld overlay after finished procedures [26]. A $75 \% \mathrm{Ar}-25 \% \mathrm{CO}_{2}$ mixture was used as shielding gas, with a flow rate of $16 \mathrm{l} / \mathrm{min}$. Direct current, with a preheat of $20^{\circ} \mathrm{C}$ and an interpass temperature of $150^{\circ} \mathrm{C}$ were adopted. The welding parameters shown in Table 2 produced a deposition rate of 3.25 $\mathrm{kg} / \mathrm{h}$.

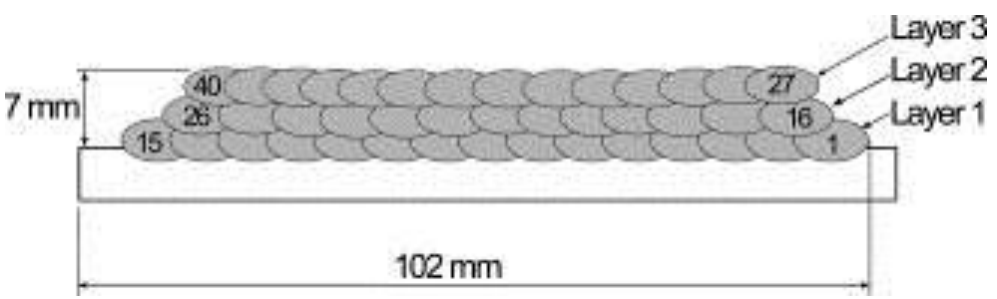

Figure 1: Scheme of the applied welding layers.

Table 2: Welding Parameters.

\begin{tabular}{l|l|l|l|l}
\hline PASS & LAYER & CURRENT (A) & VOLTAGE $(\mathbf{V})$ & WELDING ENERGY $(\mathbf{k J} / \mathbf{m m})$ \\
\hline $1-15$ & 1 & 167 & 38 & 0.66 \\
\hline $16-28$ & 2 & 185 & 38 & 0.72 \\
\hline $29-40$ & 3 & 185 & 38 & 0.72 \\
\hline
\end{tabular}

After welding, the joints were submitted to a post weld heat treatment (PWHT) at $620^{\circ} \mathrm{C}$ for 10 hours, followed by air cooling. The overlays were analyzed in both as welded and after PWHT conditions.

The metallographic examination was conducted on samples taken transversally to the weld bead. The samples were carefully ground with emery paper up to 1200 grid and polished using diamond paste with 6 
$\mu \mathrm{m}, 3 \mu \mathrm{m}$ and $1 \mu \mathrm{m}$. The microstructure was observed via optical microscopy (OM) and scanning electron microscopy (SEM) in secondary electrons and backscattered modes. Additionally, quantitative analysis of secondary phases was performed by selecting five different fields which were observed with SEM by using the backscattered mode with a nominal magnification of $1000 \mathrm{X}$. The images were collected at around $3 \mathrm{~mm}$ from the fusion line. Then, the binarization of the images was performed, followed by the calculation of phase fraction and the average size of the secondary phases. A statistical analysis of the results was performed. For the binarization and particle analysis, the Image $\mathbf{J}$ software was used.

Electron Backscattered Diffraction (EBSD) analysis was performed as well. In that case, after polishing, the samples were submitted to an additional final polishing in a colloidal silica solution with $0.25 \mu \mathrm{m}$. The EBSD maps were collected with SEM operating at $20 \mathrm{kV}$ and with step size between 1 and $4 \mu \mathrm{m}$. Semiquantitative analyses of the main elements were assessed by energy dispersive spectroscopy (EDX). The global dilution was determined in the transverse cross-section by the ratio between substrate diluted area and total diluted area with the aid of the AutoCAD software. Both areas were measured and the ratio between them was calculated.

For the evaluation of mechanical properties, bending and hardness tests usually apply, as required by the procedures used for qualification of welds [27]. In this respect, four guided side-bend tests with bend radius of $180^{\circ}$ were performed at room temperature on test specimens removed transversally to the weld deposits, in accordance with ASME IX [27]. Vickers hardness measurements with a load of 500 gf were conducted along the transverse cross-section of the deposits at points located at the weld metal, fusion line and substrate.

Chemical analyses were performed at different positions from the fusion line, by means of optical emission spectroscopy.

Finally, corrosion tests according to ASTM G 48 Method A [28] were performed at $40^{\circ} \mathrm{C}$ for 24 hours on specimens with dimensions of 50x25x3 mm.

\section{RESULTS AND DISCUSSION}

The increase in the deposition rate performed by electric arc welding processes may cause damages to the quality of the overlay, as a consequence of changes in penetration, dilution and mechanical properties. Consequently, conventional arc welding processes, such as GTAW, GMAW and SMAW processes, are usually used. However, by adopting adequate welding procedures, it can be possible to achieve the requirements for good performance of the overlays, as observed in the present work. In fact, as showed in Figure 1, the use FCAW process allowed a weld overlay free of defects with a deposition rate of $3.25 \mathrm{~kg} / \mathrm{h}$. In addition, it was calculated a dilution rate of $9.6 \%$, which can be considered low when compared to GMAW and SMAW processes, where rates greater than $10 \%$ are usual $[4,15,17,18,29,31]$. This is an important result, once the dilution has a strong effect on the corrosion resistance [32]. With such characteristics, FCAW is able to provide overlays with the necessary quality and significant gain in productivity, once it allows deposition rates higher than those promoted by the other processes. The results obtained in the present work are compatible with those obtained by other authors $[11,18,28,30]$.

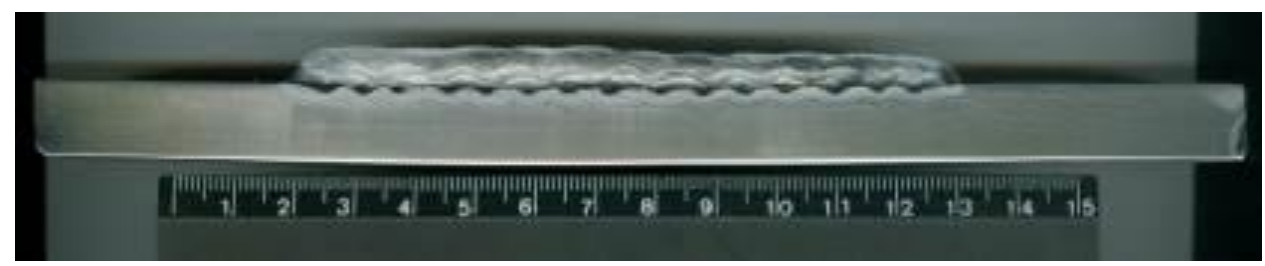

Figure 2: Macrography of the weld overlays. Etching: Aqua Regia.

Figure 3 shows the presence of Partially Diluted Zones (PDZ) along the fusion boundary. According to OMAR [33], these discontinuous and hard zones primarily along the fusion line can often lead to inservice failures, once they may cause the dissimilar weld to be susceptible to localized pitting corrosion attack, hydrogen embrittlement and sulfide stress cracking. These zones are usually associated with the presence of high-hardness martensite (higher than $400 \mathrm{HV}$ ) [8,29,30,34-36] and can promote a deleterious influence on the corrosion resistance of dissimilar metal welds for sour service. Although the occurrence of PDZ (Figure 3) and grain boundaries of Type II have been observed (Figure 4), no evidences of cracking or disbonding were verified. These results are supported by the bending (Table 3) and corrosion tests (Table 4), which showed satisfactory results for all conditions. 
As expected $[8,21,23,24,30,31,35-38]$, martensite is the microstructural constituent observed at PDZ. It is important to notice the difference of morphology between the martensite in the PDZ and the martensite close to the fusion line (Figure 5); this difference can be attributed to the chemical composition, once the martensite of PDZ is richer in carbon. Consequently, lower hardness is expected for the martensite observed at CGHAZ, as observed in the present work (Figure 6).

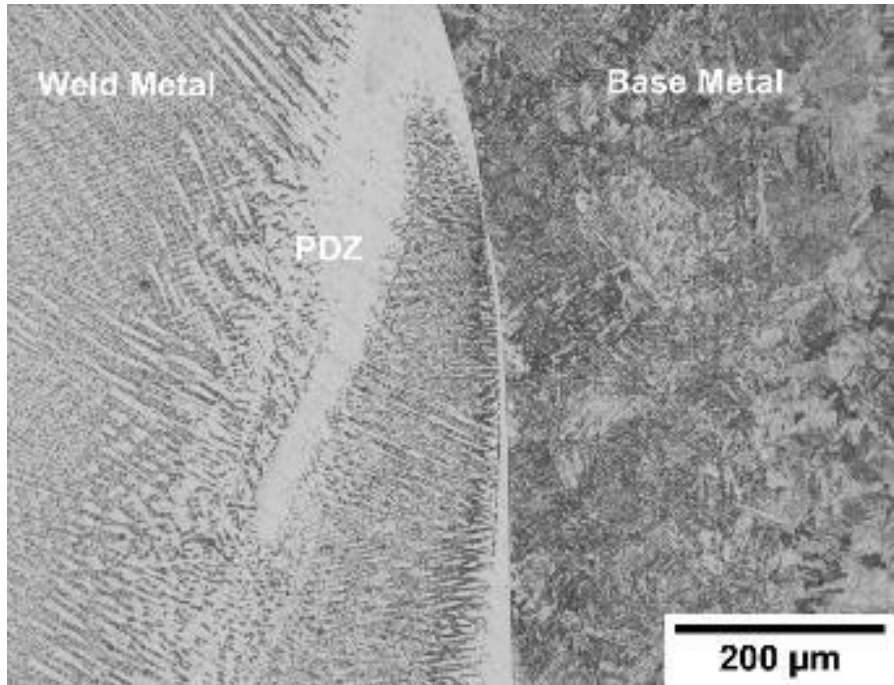

Figure 3: Optical microscopy near the fusion line showing occurrence of PDZ. Etching: 10\% Oxalic Acid for weld metal and Villela Reagent for base metal.
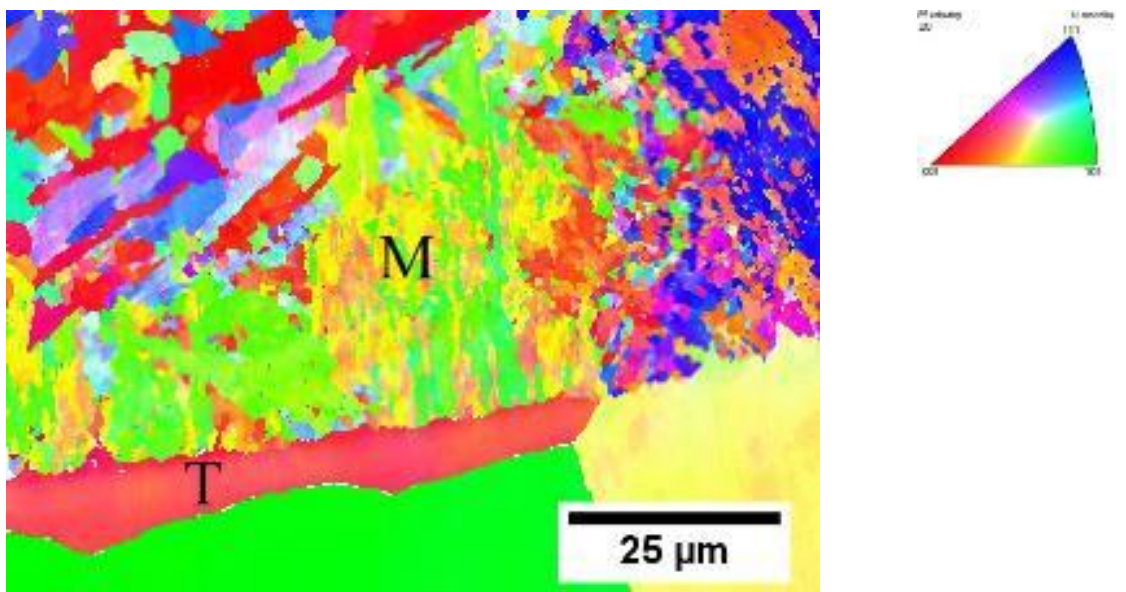

Figure 4: Martensite (M) at CGHAZ and grain boundaries of type II at weld metal (T) as observed by EBSD.

Table 3: Results of bending tests.

\begin{tabular}{l|l|l}
\hline CONDITION & \multicolumn{1}{|c|}{ RESULTS $\left(^{*}\right)$} & \multicolumn{1}{c}{ COMMENTS } \\
\hline As welded & Approved & No evidence of discontinuities \\
\hline PWHT & Approved & No evidence of discontinuities \\
\hline
\end{tabular}

(*) Acceptance criteria [27] - no open discontinuity exceeding $1.6 \mathrm{~mm}$ measured in any direction in the cladding and no open discontinuity exceeding $3.2 \mathrm{~mm}$ along the approximate weld interface. 
Table 4: Results of corrosion tests according to ASTM G48 [28].

\begin{tabular}{l|l|l}
\hline CONDITION & PITTING & WEIGHT LOSS $\left(\mathbf{g} / \mathbf{m}^{2}\right)$ \\
\hline As Welded & No & 0.34 \\
\hline Post Weld Heat Treated & No & 0.34 \\
\hline Required [29] & No & $<4.0$ \\
\hline
\end{tabular}

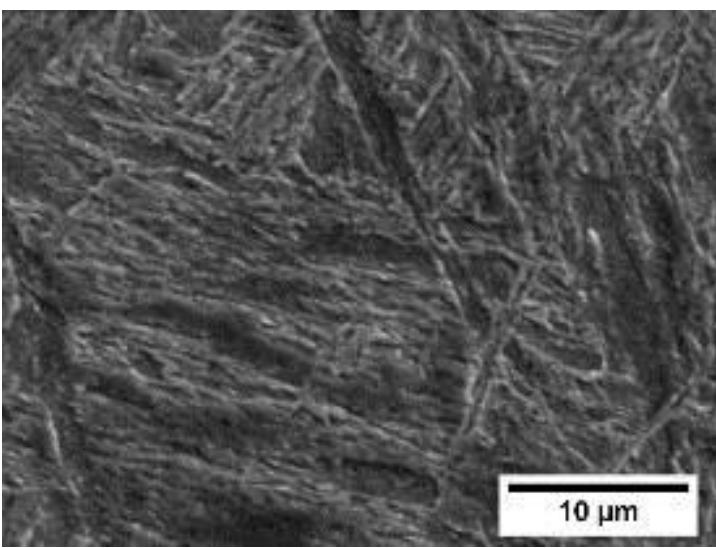

CGHAZ $\left(254 \mathrm{HV}_{0.5}\right)$

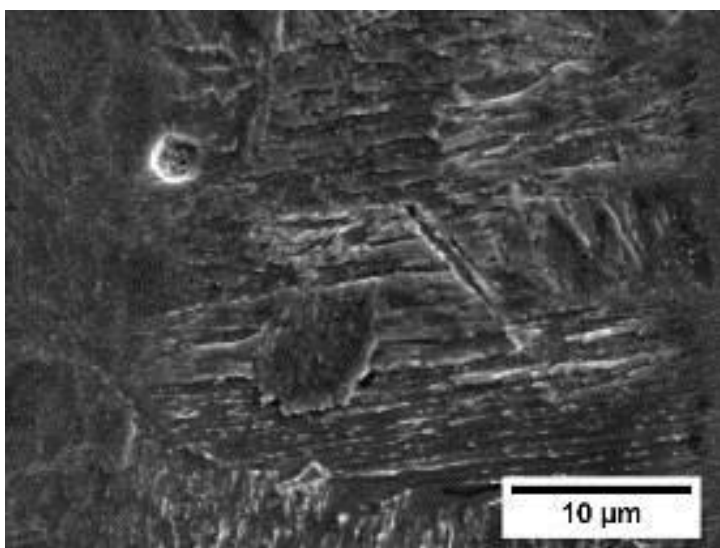

$\operatorname{PDZ}\left(376 \mathrm{HV}_{0.5}\right)$

Figure 5: Detail of martensite present at different positions for the overlay. Etchant: Nital 2\%.

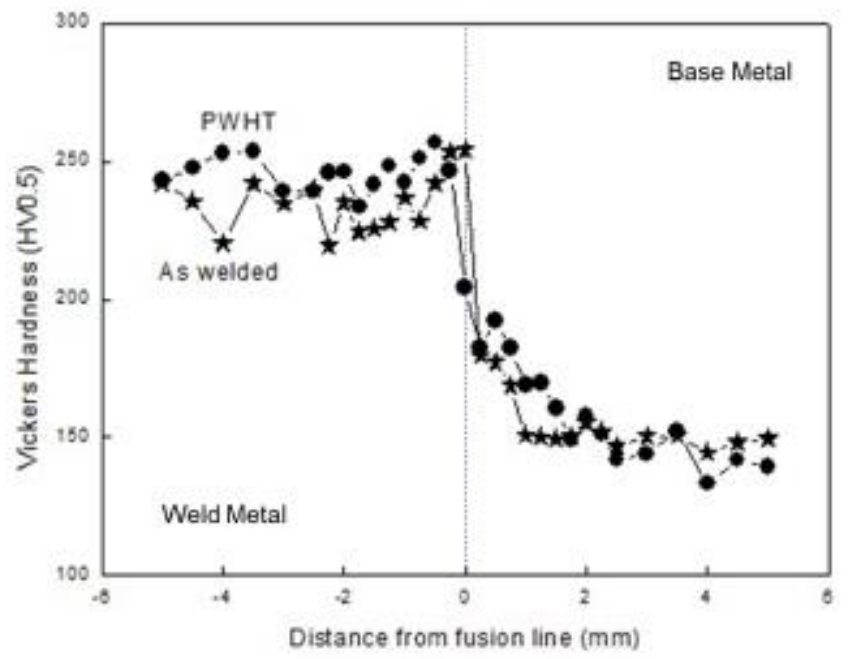

Figure 6: Hardness measurements at specific positions from the fusion line.

With respect to the weld metal, Figure 7 shows a fully austenitic microstructure with a solidification form that mainly appears in Inconel cladding steel materials [13]. Moreover, a high level of segregation and different types of secondary phases (SP) is observed (Figure 8). EDS analysis of weld metal, in dendritic and interdendritic regions (Table 5), confirmed that primary face centered cubic $\gamma$ (Ni-FCC) dendrites are richer in $\mathrm{Ni}$ and $\mathrm{Cr}$ and in the interdendritic regions a higher percentage of $\mathrm{Nb}$ and $\mathrm{Mo}$ is observed. Based on the results presented in Table 5, the values of the partition coefficient calculated for $\mathrm{Nb}(0.52)$, Mo (0.99), $\mathrm{Cr}$ (1.09) and $\mathrm{Ni}$ (1.12), indicate that Mo and $\mathrm{Nb}$ segregate during solidification into the liquid and, once solidification is finished, the interdendritic regions are considerably enriched with these elements, since values of $k$ for $\mathrm{Mo}$ and $\mathrm{Nb}$ are lower than 1 . These results are in accordance with other works $[3,6,8,12,14,19,39,40]$. 
Table 5: Elemental composition range (wt. \%) of secondary phases and the austenitic matrix measured via EDS microanalysis.

\begin{tabular}{l|l|l|l|l}
\hline POSITION / ELEMENT, wt\% & $\mathbf{C r}$ & $\mathbf{N i}$ & Mo & Nb \\
\hline Matrix (ID) & 14.46 & 44.07 & 6.33 & 1.83 \\
\hline Matrix (D) & 15.72 & 49.21 & 6.38 & 0.96 \\
\hline SP1 & 12.49 & 36.48 & 19.58 & 18.77 \\
\hline SP2 & 8.33 & 15.81 & 10.75 & 68.40 \\
\hline
\end{tabular}

Where: D - Dendritic region; ID - Interdendritic region; SP - Secondary Phase

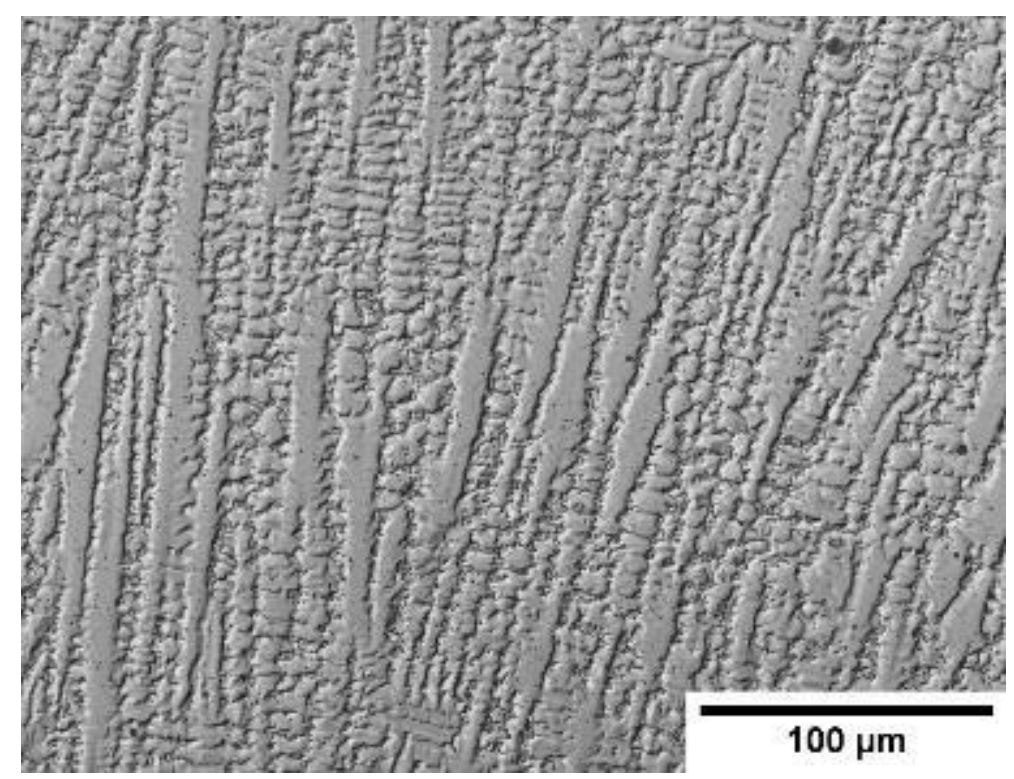

Figure 7: Optical microscopy of the weld metal with Nomarski technique. Etching: Oxalic Acid.

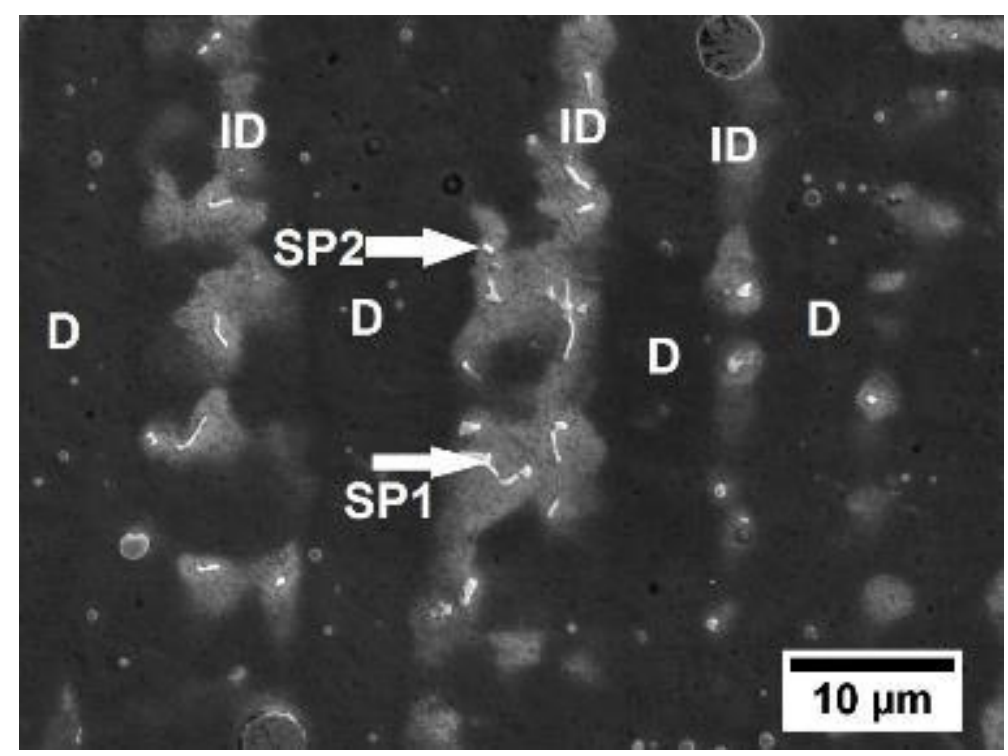

Figure 8: Microstructure of the weld metal (SEM); Etching: $\mathrm{CrO}_{3}$ electrolytic.

D - Dendritic region; ID - Interdendritic region; SP - Secondary Phase

According to CIESLAK et al. [41], niobium free alloys solidify in a simple L $\rightarrow \gamma$ transformation 
without any eutectic-like reaction and exhibit a relatively narrow solidification temperature range. On the other hand, $\mathrm{Nb}$-bearing alloys solidify according to an eutectic-type reaction between $\gamma$ and several $\mathrm{Nb}$-rich phases such as $\mathrm{NbC}$ and Laves. DU PONT et al.[23] state that the following sequence occurs in Nb-bearing alloys: $\mathrm{L} \rightarrow \mathrm{L}+\gamma \rightarrow \mathrm{L}+\gamma+\mathrm{NbC} \rightarrow \mathrm{L}+\gamma+\mathrm{NbC}+\mathrm{M} 6 \mathrm{C} \rightarrow \mathrm{L}+\gamma+\mathrm{NbC}+\mathrm{M} 6 \mathrm{C}+$ Laves $\rightarrow \gamma+$ $\mathrm{NbC}+\mathrm{M} 6 \mathrm{C}+$ Laves.

Estimates of secondary phases formed during welding were made using Thermo-calc software, based on the TTNI8 database. The occurrence of Laves phase and NbC are predicted by the pseudo-binary diagram (Figure 9) which shows that the Laves phase is favored by the increasing $\mathrm{Nb}$ contents. It is important to remark that pseudo binary phase diagrams are more adequate to estimate phases than the Scheil diagrams, due to the repetitive thermal influence from the several welding passes. Although many other phases are predicted, they were not observed, which can be attributed to the precipitate-formation kinetics [42].

Considering the above discussed, associated with the results obtained by EDS analysis (Table 5) and the findings of many other authors [3,8,12,23,39,40,43-46], it seems reasonable to point out the very low proportion of secondary phases observed in the present work (Table 6) as Laves phase rich in Mo and $\mathrm{Nb}$ and $\mathrm{Nb}$ carbides.

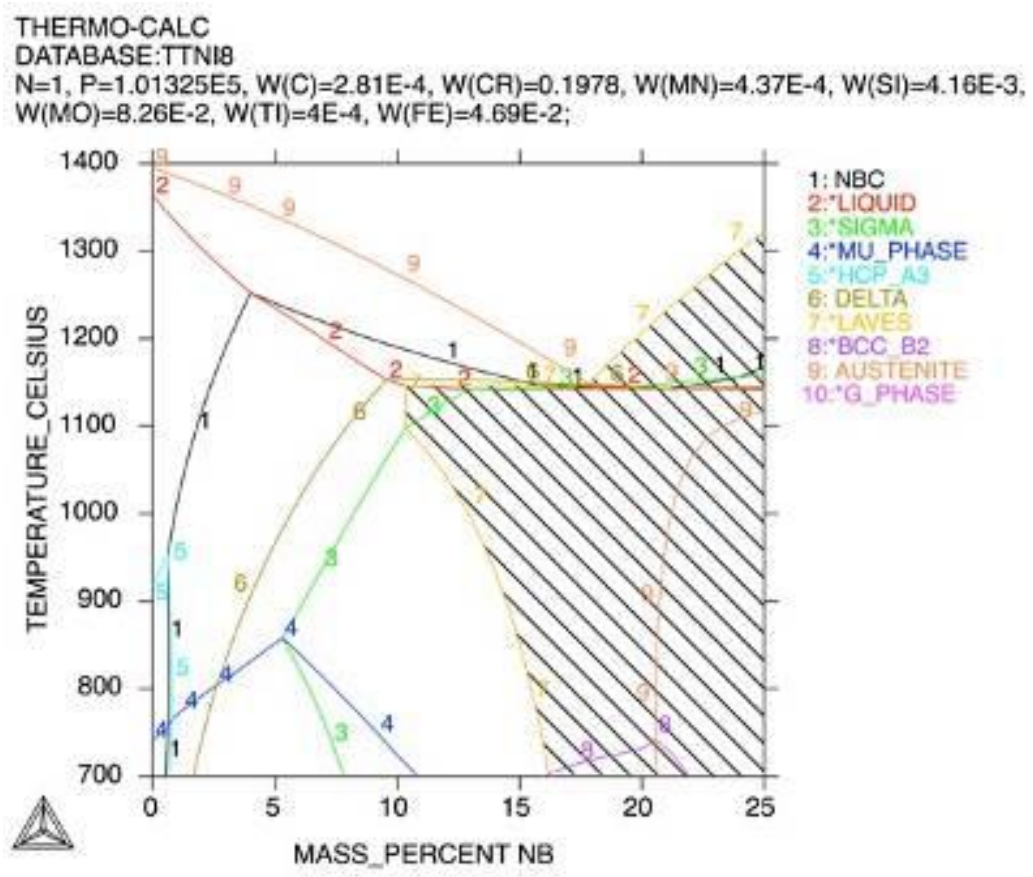

Figure 9: Pseudo-binary diagram obtained from Thermo-Calc software.

Table 6: Secondary phase fraction for as-welded and PWHT conditions.

\begin{tabular}{l|l}
\hline CONDITION & PHASE FRACTION OF SECONDARY PHASES (\%) \\
\hline As welded & 0.422 \\
\hline PWHT & 0.354 \\
\hline
\end{tabular}

As expected, due to low welding energy applied, a microstructure composed primarily by martensite at CGHAZ was observed by SEM (Figure 5) and confirmed by EBSD technique (Figure 4) [47-50]. However, as a consequence of reheating due to multiple passes, low hardness was observed at this region (Figure 6) due to the tempering of the martensite.

Although the mechanical properties of solid solution strengthened nickel-based alloys are often appropriate for the specific application in the as-welded condition, PWHT is sometimes recommended to the relief of residual stresses of industrial components [19,23,51-54]. In addition, PWHT can contribute to the mechanical properties of the HAZ. In this respect, SHARMA et al. [55] state that if the PWHT is conducted at an appropriate temperature and time, the welded joint exhibits good mechanical properties. However, if the PWHT temperature is too low or too high, the properties can be inadequate due to insufficient or over tempering effect. 
Particularly in regard to the nickel-based superalloy Inconel-625, some works $[2,10,46,56]$ studying the effect of PWHT for temperatures between $600^{\circ} \mathrm{C}$ and $700^{\circ} \mathrm{C}$ did not observe considerable changes on the microstructure and mechanical properties of weld metal, as observed in the present work. At the heat affected zone (HAZ), PWHT promoted the tempering of martensite with the consequent reduction of hardness at CGHAZ (Figure 6). The results of hardness tests are in accordance with the microstructure observed (Figure 5) and are consistent with those obtained in other works [57-59].

Considering all results obtained in the present work, a good performance is also expected on corrosion tests for all conditions. Indeed, as stated by Zaharani et al. [60], by decreasing the heat input and, particularly for FCAW process, increasing the deposition rate the dilution level and Fe content in the overlay will be minimized. This can lead to improving the corrosion resistance of the weld overlay. The results showed in Table 4 , confirm that all requirements are achieved, as well as they do not show significant differences for the conditions considered in this work. Basically, this behavior can be attributed to the association of low dilution $(<$ $10 \%$ ), and $\mathrm{Fe}$ content inferior to $5 \%$ at $3.0 \mathrm{~mm}$ from fusion line (Table 7 and Figure 10), which is the recommended minimum thickness required for weld overlay applied in corrosive hydrocarbon systems [7, 8, 15, $18,46,61,62]$. In addition, these results are in accordance to other works [17, 46, 60, 63], which states that satisfactory corrosion results are obtained when welding parameters and dilution are controlled.

The association of all evidences discussed previously allows the conclusion that the weld overlay performed by FCAW process with higher productivity, resulted in adequate properties for all conditions, despite the secondary phases and the occurrence of PDZ. All requirements for mechanical and corrosion tests were met and PWHT performed at $620^{\circ} \mathrm{C}$ did not promote significant changes on the properties. This confirms the feasibility of the application of the FCAW process for nickel based superalloy Inconel 625 weld overlays.

Table 7: Chemical composition at different positions from fusion line.

\begin{tabular}{l|c|c|c|c|c|c|c|c|c}
\hline $\begin{array}{l}\text { ELEMENT (wt\%) DISTANCE } \\
\text { FROM THE FUSION LINE (mm) }\end{array}$ & $\mathbf{C}$ & $\mathbf{C r}$ & $\mathbf{N i}$ & $\mathbf{M n}$ & $\mathbf{S i}$ & $\mathbf{M o}$ & $\mathbf{N b}$ & $\mathbf{T i}$ & $\mathbf{F e}$ \\
\hline 5.67 & 0.02 & 20.22 & Bal. & 0.02 & 0.42 & 8.77 & 3.09 & 0.06 & 1.19 \\
\hline 4.00 & 0.02 & 19.97 & Bal. & 0.02 & 0.42 & 8.64 & 3.05 & 0.04 & 2.08 \\
\hline 2.00 & 0.03 & 19.78 & Bal. & 0.04 & 0.41 & 8.26 & 2.84 & 0.04 & 4.69 \\
\hline 1.00 & 0.05 & 17.27 & Bal. & 0.18 & 0.39 & 6.76 & 2.38 & 0.03 & 16.76 \\
\hline 0.00 & 0.09 & 15.48 & Bal. & 0.33 & 0.34 & 5.58 & 1.68 & 0.02 & 28.33 \\
\hline 1.00 & 0.23 & 0.79 & 1,59 & 1.09 & 0.26 & 0.21 & 0.12 & 0.03 & 95.60 \\
\hline Required & - & $20-23$ & $58(\mathrm{~min})$ & - & - & $8-10$ & - & - & $5(\max )$ \\
\hline
\end{tabular}

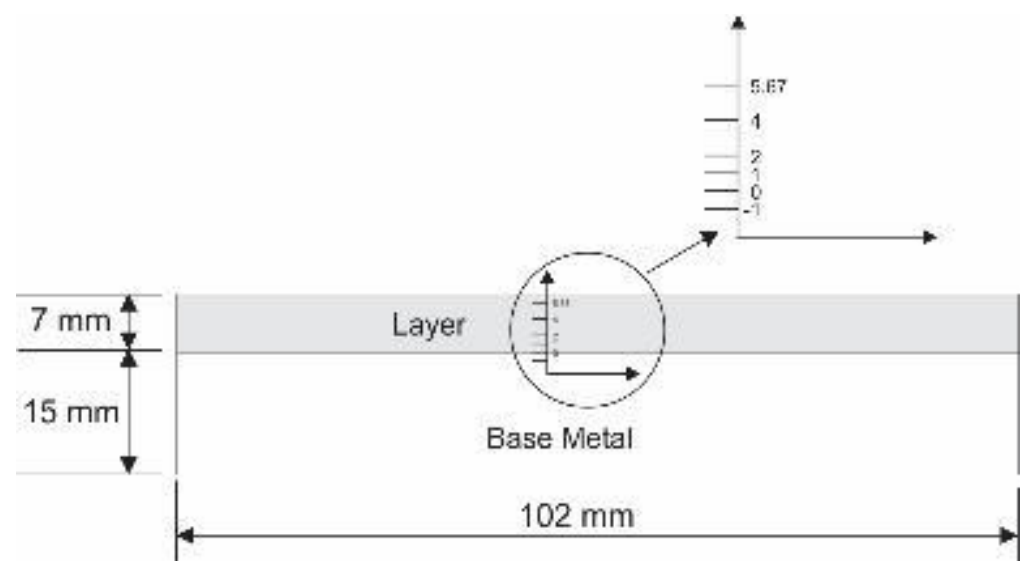

Figure 10: Schematic of the chemical analysis points through the layer. 


\section{CONCLUSION}

The results obtained in the present work confirms the feasibility of the FCAW process as an interesting alternative for nickel based superalloy Inconel 625 weld overlays, since satisfactory mechanical and corrosion properties were obtained, despite the secondary phases and the occurrence of PDZ, for the as welded and stress relieved conditions. Also, an improvement on productivity as compared to conventional processes was seen.

\section{ACKNOWLEDGEMENTS}

The authors thank CEFET/RJ, COPPE-UFRJ and Petrobras for the support in the execution of the present work.

\section{BIBLIOGRAPHY}

[1] TRINDADE, V.B., SOUZA, E.S., DE PAULA, J.M.A., et al., "Efeito de diferentes tratamentos térmicos sobre microestrutura e microdureza de um sistema Aço C-Mn/ Revestimento de Inconel 625", Tecnologia em Metalurgia, Materiais e Mineração, v. 14, n 2, pp. 167-174, 2017.

[2] SUKUMARAN, A., GUPTA, R.K., KUMAR, V.A., "Effect of heat treatment parameters on the microstucture and properties of Inconel -625 superalloy", Journal of Materials Engineering and Performance, v. 26, n. 7, pp. 3048-3057, 2017.

[3] GORNIKOWSKA, M.R., BLICHARSKI, M., "Microsegregation and precipitates in Inconel 625 arc weld overlay coatings on boiler pipes", Arquives of Metallurgy and Materials, v. 60, n 4, pp. 2599-2605, 2016.

[4] POSCH, G., SCHERLEITNER, W., RUTZINGER, B., et al., Manufacturing of nickelbase-overlays: Comparison of various welding technologies under consideration of clad properties, In: IIW International Congress IC 2014, New Delhi, India, 2014.

[5] MORADI, M., KETABCHI, M., "An experimental study of microstructure and mechanical behavior of alloy 625 weld overlay deposited on ASTM A516 grade 70, Indian Journal of Science and Technology, v. 8, n.12, pp.1-6, 2015.

[6] ANTOSZCZYSZYN, T.J., PAES, R.M.G, OLIVEIRA, A.S.C.M., et al., "Impact of dilution on the microstructure and properties of Ni-based 625 alloy coatings", Soldagem \& Inspeção, v.19, n. 2, pp. 134-144, 2014.

[7] ELANGO, P., BALANGURU, S., "Welding parameters for Inconel 625 overlay on carbon steel using GMAW", Indian Journal of Science and Technology, v. 31, n. 8, pp.1-5, 2015.

[8] SILVA, C.C., AFONSO, C.R.M., RAMIREZ, A.J., et al., "Aspectos metalúrgicos de revestimentos dissimilares com a superliga a base de níquel Inconel 625", Soldagem \& Inspeção, v. 17, n. 3, pp. 251-263, 2012.

[9] GORNIKOWSKA, M.R., BLICHARSKI, M., KUSISNSKI, J., "Influence of weld overlaying methods on microstructure and chemical composition of Inconel 625 boiler pipe coatings", Kovove Materials, v. 52, p. $1-7,2014$.

[10] CORTIAL, F., CORRIEU, J.M., VERNOT-LOIER, C., "Heat treatments of weld alloy 625: Influence on the microstructure, mechanical properties and corrosion resistance", In Proceedings of the Superalloys 718, 625, 706 and Various Derivatives, The Minerals, Metals \& Materials Society, pp. 859-870, 1994.

[11] KEJELIN, N.Z., BUSCHINELLI, A.J.A., BOHORQUEZ, C.H.N., Dissimilar metal welding of X-60 steel with Inconel 625, Proceedings of the $32^{\circ}$ Brazilian Welding Congress, Belo Horizonte, Brazil, pp.1-14, 2006.

[12] SILVA, C.C., MIRANDA, H.C., MOTTA, M.F., et al., "New insight on the solidification path of an alloy 625 weld overlay", Journal of Materials Research and Technology, v. 2, n.3, pp. 228-237, 2013.

[13] KIM, J.S., PARK, Y.I., LEE, H.W., "Effects of Heat Input on the Pitting Resistance of Inconel 625 Welds by Overlay Welding", Met. Mater. Int., v. 21, n. 2, pp. 350-355, 2015.

[14] MINÁ, E.M., SILVA, Y.C., DILLE, J., et al., "The effect of dilution on microsegregation in AWS ER NiCrMo-14 alloy welding claddings", Metallurgical and Materials Transactions A, v. 47, n. 12, pp. 61386147, 2016.

[15] RUTZINGER, B., "Influence of the welding process to the dilution rate of weld overlays on unalloyed 
steel using the weld consumable ERNiCrMo3(Alloy 625)", Biuletyn Instytutu Spawalnictwa, v. 58, n .5, pp.72-75, 2014.

[16] RIBEIRO, R.A., GONÇALVES, R.B., PARANHOS, R.P.R., "Caracterização de uma junta dissimilar entre aço carbono e Inconel 625 obtida por soldagem por explosão", Soldagem \& Inspeção, v. 22, n.1, pp.213, 2017.

[17] NETO, F.A.S, CUNHA, M.C.D., SANTOS, A.X., et al., "Análise da resistência a corrosão de revestimentos a base da liga de níquel depositados por soldagem em aço API 5L Gr B", Revista Brasileira de Aplicações de Vácuo, v. 35, n. 3, pp.144-150, 2016.

[18] SANTOS, A.X., MACIEL, T.M., SANTANA, R.A.C., "Avaliação de revestimentos a base de Inconel 625 depositados através do processo de soldagem GMAW em aco API 5L X70 utilizando Planejamento Fatorial”, Revista Brasileira de Aplicações de Vácuo, v. 34, n. 3, pp. 128-140, 2015.

[19] SANTOS, A., POSSEBON, S., MARTINS, F.J.S., "Soldagem de tubulações revestidas utilizando metal de adição NiCrMo-3 (liga de níquel 625): Aspectos metalúrgicos", Proceedings of the $39^{\circ}$ Brazilian Welding Congress, Curitiba, Brazil, 2013.

[20] CAVAlCANTE, N.E., ANDRADE, T.C., PINHEIRO, P.H.M., et al., "Estudo de procedimentos de soldagem MIG/MAG para aplicação de revestimentos de liga de níquel Inconel 625 em aço estrutural ASTM A387 Gr.11”, Soldagem \& Inspeção, v. 21, n.1, pp.70-82, 2016.

[21] GORNIKOWSKA, M.R., BLICHARSKI, M., "TEM microstructure and chemical composition of transition zone between steel tube and an Inconel 625 weld overlay coating produced by CMT method, Arquives of Metallurgy and Materials, v. 62, n. 2, pp. 787-793, 2017.

[22] SAHA, M.K., DAS, S., "A review on different cladding techniques employed to resist corrosion”, Journal of the Association of Engineers, v. 86, n. 1-2, pp.52-63, 2016.

[23] DU PONT, J.N., LIPPOLD, J.C., KISER, S.D., Welding Metallurgy and Weldability of Nickel-Based Alloys, John Wiley \& Sons, Inc., New Jersey, 2009.

[24] ALEXANDROV, B.T., LIPPOLD, J.C., SOWARDS, J.W., et al., "Fusion boundary microstructure evolution associated with embrittlement of Ni-base alloy overlays applied to carbon steel", Welding in the World, v. 57, n.1, pp.9-53, 2013.

[25] American Welding Society, Specification for Nickel Alloy Electrodes for Flux Cored Arc Welding, AWS A5.34/A5.34M:2013, Miami, 2013.

[26] Norsok Standard, Specification M-001, Materials Selection, Rev.3, Oslo - Norway, November, 2002.

[27] American Society for Mechanical Engineers, Qualification Standard for Welding and Brazing Procedure, 2012.

[28] ASTM G 48, 2009 - Standard Test Methods for Pitting and Crevice Corrosion Resistance of Stainless Steels and Related Alloys by Use of Ferric Chloride, 2009.

[29] Norsok M-601; Welding and Inspection of Piping, Rev. 4, 2004.

[30] MYRES, D., "Metal cored wires: advantages e disadvantages", Welding Journal, v. 81, n. 9, pp.39-42, 2002.

[31] JORGE, J.C.F., MEIRA, O.G., MADALENA, F.C.A., et al., "Evaluation of the AISI 904L alloy weld overlays obtained by GMAW and electro-slag welding processes, Journal of Materials Engineering and Performance, v. 26, n. 5, pp. 2204-2212, 2017.

[32] MURUGAN, N., PARMAR, R.S., Stainless steel cladding deposited by automatic gas metal arc welding”, Welding Journal, v. 76, n. 10, pp. 391-310, 1997.

[33] KIM, J.S., PARK, Y.I., LEE, H.W., "Effects of Heat Input on the Pitting Resistance of Inconel 625 Welds by Overlay Welding”, Met. Mater. Int., v. 21, n. 2, pp. 350-355, 2015.

[34] OMAR, A. A., "Effects of welding parameters on hard zone formation at dissimilar metal welds", Welding Journal, v.77, n 2, pp.83s-93s, 1998.

[35] BATISTA, V.R., ARAÚJO, E.M., FRAGA, R., et al., Caracterização da interface de depósitos de solda de INCONEL 625 sobre aços AISI 8630 e AISI 4130 temperados e revenidos, In: Proceedins of the $22^{\circ}$ CBECiMat - Congresso Brasileiro de Engenharia e Ciência dos Materiais, 06 a 10 de Novembro de 2016, Natal, RN, Brasil, p.1-14, 2016.

[36] DOODY, T., "Intermediate mixed zones in dissimilar metal welds for sour service", Welding Journal, v. 71, n. 3, pp.55-60, 1992. 
[37] KEJELIN, N.Z., BUSCHINELLI, A.J.A., POPE, A.M., "Effect of Welding Parameters on the Partially Diluted Zones Formation at Dissimilar Metal Welds", In: Proceedings of the 18th International Congress of Mechanical Engineering, Ouro Preto, Brazil, 2005.

[38] DU PONT , J.N., AND KUSKO, C.S., "Technical note: martensite formation in austenitic/ferritic dissimilar alloy welds", Welding Journal, v. 86, n.2, p.51s-54s, 2007.

[39] DI, J.X., CHEN, B., "High chromium nickel base alloy weld deposited metal", Science and Technology of Welding and Joining, v. 20, n. 4, pp.325-329, 2015.

[40] PETRZAK, P., BLICHARSKI, M., DYMEK, S., et al., "Electron microscopy investigation of Inconel 625 weld overlay on boiler steel”, Solid State Phenomena, v. 231, pp.113-118, 2015.

[41] CIESLAK, M.J., KNOROVSKY, G.A., HEADLEY, T.J., et al., A.D., 1989. "The Solidification Metallurgy of Alloy 718 and Other Nb-Containing Superalloys", In Proceedings of the Superalloy 718. Warredale, PA.

[42] ANBURAJ, J., MOHAMED NAZIRUDEEN, S.S., NARAYANAN, R., et al., "Ageing of forged superaustenitic stainless steel: Precipitate phases and mechanical properties", Materials Science and Engineering A, v.535, pp.99- 107, 2012.

[43] XU, F., LIU, Y., SHU, F., et al., "Microstructural evolution and mechanical properties of Inconel 625 alloy during pulsed plasma are deposition process", Journal of Materials Science and Technology, v. 29, n.5, pp.480-488, 2013.

[44] DU PONT, J.N., "Solidification of an alloy 625 weld overlay", Metallurgical and Materials Transactions A, v.27A, n.11, pp. 3612-3620, 1996.

[45] CIESLAK, M.J., "The Welding and Solidification Metallurgy of Alloy 625”, Welding Journal, v. 70, n. 2, pp. 49-56, 1991.

[46] SANDES, S.S., ALVARÃES, C.P., MENDES, M.C., et al., “Avaliação de revestimentos de liga de níquel 625 depositados pelo processo eletroescória”, Soldagem \& Inspeção, v. 21, n. 4, pp.417-427, 2016.

[47] GOURGUES, A.F., FLOWER, H.M., LINDLEY, T.C., "Electron backscattering diffraction study of acicular ferrite, bainite, and martensite steel microstructures", Materials Science and Technology, v. 16, n.1, pp.26-40, 2000.

[48] KARTHIKEYAN, T., DASH, M.K., SAROJA, S., et al., "Estimation of martensite feature size in a lowcarbon alloy steel by microtexture analysis of boundaries, Micron, v. 68, p.77-90, 2015.

[49] NARAYANAN, B.K., KOVARIK, L., QUINTANA, M.A., et al., "Characterization of ferritic weld microstructures using various electron microscopy techniques: a review", Science and Technology of Welding and Joining, v. 16, n.1, pp. 12-22, 2011.

[50] SUIKKANEN, P., CYRON, C., DEARDO, A. J., "Crystallographic analysis of martensite in 0.2C2.0Mn-1.5Si-0.6Cr steel using EBSD”, Journal of Materials Science and Technology, v. 27, n. 10, pp.920930, 2011.

[51] COSTA, E.C., Caracterização dos aços SAE 8630 modificado e amanteigado com Inconel 625 pelo processo de soldagem MIG, Dissertação de M.Sc., UFPB, Paraíba, Brasil, 2013.

[52] SAMIR, M, 2015, “A review of effect of welding and post welding heat treatment on microstructure and mechanical properties of Ggrade 91 steel”, International Journal of Research in Engineering and Technology, v.4, n.3, pp.574-580, 2015.

[53] YUNJIAN, W., PATCHETT,B. M., BICKNELL, C., "The interfacial microstructure of weld overlay of corrosion resistant alloys”, Scripta Metallurgica \& Materialia, v.30, n. 9, pp.1133-1138, 1994.

[54] SHEN, R.R., ZHOU, Z., LIU, P., et al., " Effects of PWHT on the microstructure and mechanical properties of ERNiCrFe-7 all-weld metal”, Welding in the World, v. 59, n.3, pp.317-323, 2015.

[55] SHARMA, A., VERMA, D.K, KUMARAN, S., "Effect of post weld heat treatment on mechanical properties of hot wire GTA welded joints of SA213 T91 Steel", In: Proceedings of IRF International Conference, 22nd January 2017, Bengaluru, India, pp.20-23, 2017.

[56] BAN, S., SHIN, Y.T., LEE, S.R., et al., "Corrosion resistance of Inconel 625 overlay welded inside pipes as a function of heat treatment temperature", International Journal of Electrochemical Science., vol 11, pp. $7764-7774,2016$.

[57] MADALENA, F.C.A, JORGE, J.C.F., SOUZA, L.F.G., et al., "Study of mechanical and microstructural properties of the superaustenitic stainless steel AISI 904L used as internal overlay into pressure vessels man- 
ufactured in carbon steel ASTM A-516 grade 70", In: Proceedings of the $7^{\circ}$ Brazilian Congress of Manufacturing Engineering, Penedo, Brazil, pp.1-12, 2013.

[58] ALVARÃES, C.P., MADALENA, F.C.A., ARAÚJO, L.S., et al., "Properties of Inconel 625 alloy's weld overlay obtained through flux cored arc welding and shielded metal arc welding processes", In: Proceedings of the $70^{\circ}$ Annual Congress of ABM, Rio de Janeiro, Brazil, pp. 1-12, 2015.

[59] NETO, F.A.S, ARAÚJO, F.S., MACIEL, F., et al., "Evaluation of weld parameters for cladding application with nickel alloy used in oil and gas industry", In: Proceedings of the $65^{\circ}$ Annual Congress of ABM, Rio de Janeiro - RJ, Brazil, pp.1-15, 2010.

[60] ZAHARANI, E.M., ALFANTAZI, A.M., "Hot corrosion of Inconel 625 overlay weld cladding in smelting off-gas environment", Metallurgical and Materials Transactions A, v. 44A, pp.4671-4699, 2013.

[61] FERRARI, M., "Qualificação de procedimento de soldagem para juntas de união em tubulações de API $5 \mathrm{~L}$ - X60 revestidas internamente com liga de níquel 625", In: Proceedings of the $37^{\circ}$ Brazilian Welding Congress, Natal, Brasil, pp.1-10, 2011.

[62] API 6A/ISO 10423:2004 - "Specification for Wellhead and Christmas Tree Equipment" - 19th Edition.

[63] ABIODE, T.E., MCCARTNEY, D.G., CLARE, A.T., "Laser cladding of Inconel 625 wire for corrosion protection”, Journal of Materials Processing Technology, v.217, pp. 232-240, 2015.

\section{ORCID}

Camila Pereira Alvarães

Francisco Carlos Albuquerque Madalena

Luís Felipe Guimarães de Souza

Jorge Carlos Ferreira Jorge

Leonardo Sales Araújo

Matheus Campolina Mendes
http://orcid.org/0000-0001-8106-015X

http://orcid.org/0000-0001-9133-3641

http://orcid.org/ 0000-0002-6669-8451

http://orcid.org/0000-0001-8312-0312

http://orcid.org/0000-0001-5564-0695

http://orcid.org/0000-0001-7755-2784 